\title{
Does Mean Platelet Volume in Children with Bronchiectasis Predict Exacerbations?
}

\author{
Pinar UYSAL, Tuba TUNCEL, Duygu O. ERGE, Arzu B. HOCAOGLU, \\ Ozkan KARAMAN, Nevin UZUNER
}

Dokuz Eylul University Hospital, Department of Pediatrics, Division of Allergy, Izmir, TURKEY

\begin{abstract}
Bronchiectasis is a parenchymal lung disease which develops as a consequence of chronic inflammation and recurrent pulmonary infections. It is known that platelets have a role in inflammation and progressive pulmonary damage. Mean platelet volume (MPV) values as a marker of platelet activation, and might be used as an indicator of inflammation. Eighty-one children with the diagnosis of bronchiectasis followed between July 2010-July 2012 were enrolled in the study. The demographical data of patients were recorded and complete blood count (CBC) and MPV values were screened via hospital patient database. Complete blood count and MPV values were compared to age and sex-matched healthy children's data. In addition, CBC and MPV values were compared among chronic disease period without any exacerbation and exacerbation period in the children with bronchiectasis. The study was consisted of 81 children with bronchiectasis and 79 healthy controls. There was no significant difference between MPV values of non-exacerbation period and control group ( $p>0,05)$. Mean platelet volumes during acute exacerbation were significantly lower when compared with the values of non-exacerbation period and controls ( $p=0,02$ and $p=0,01$ respectively). MPV and platelet counts $(r=-0,502, p=0,01)$ as well as leucocyte count and hemoglobin levels were inversely correlated with each other in exacerbation period $(r=-439, p=0.00)$. Mean platelet volume measured at during acute exacerbation were significantly decreased in children with bronchiectasis. With the result of present study, we suggest that MPV might be used as a predictor marker for diagnosis of acute exacerbations in children with bronchiectasis.
\end{abstract}

Keywords: Mean platelet volume, Bronchiectasis, Childhood

\section{ÖZET}

Ortalama Trombosit Hacmi Bronşektazili Çocuklarda Alevlenmeleri Öngörebilir mi?

Bronşektazi kronik enflamasyon ve tekrarlayan akciğer enfeksiyonlarının sonucunda gelişen parankimal akciğer hastalığıdır. Trombositlerin enflamasyonda ve ilerleyici akciğer hasarında rolünün olduğu bilinmektedir. Ortalama trombosit hacmi (OTH) trombosit aktivasyonunu gösteren bir değerdir ve enflamasyonda bir belirteç olarak kullanılabilir. Temmuz 2010 ile Temmuz 2012 arasında bronşektazi tanısı ile izlenen 81 çocuk çalışmaya alınmıştır. Hastaların demografik verileri kaydedilmiş ve tam kan sayımı (TKS) ve OTH değerleri hastanenin hasta kayıt sisteminden elde edilmiştir. Tam kan sayımı ve OTH değerleri yaş ve cinsiyeti eş olan sağlıklı çocukların değerleri ile karşılaştııımıştır. Ayrıca, bronşektazisi olan çocukların alevlenmenin olmadığı kronik hastalık döneminde ve alevlenme dönemindeki TKS ve OTH değerleri kendi aralarında karşılaştırımıştır. Çalışmaya 81 bronşektazili çocuk ile 79 sağlıklı çocuk alınmıştır. Alevlenmenin olmadığı dönemde bakılan OTH değerleri ile kontrol grubu arasında fark saptanmamıştır ( $p>0,05)$. Ortalama trombosit hacmi akut alevlenme döneminde alevlenme olmayan döneme ve kontrol grubuna göre anlamlı olarak düşük bulunmuştur ( $p=0,02$ ve $p=0,01$, sırasıyla). OTH ve trombosit sayıları ile birlikte lökosit sayısı ve hemoglobin seviyesi alevlenme döneminde birbirleri ile ters orantılı bulunmuştur( $r=-439, p=0.00)$. Bronşektazili çocuklarda alevlenme döneminde ölçülen Ortalama Trombosit Hacmi belirgin olarak düşüktür. Bu çalısmanın sonucunda, OTH'nin bronşektazili çocuklarda akut alevlenmelerin öngörülmesinde bir belirteç olarak kullanılmasını önermekteyiz.

Anahtar Kelimeler: Ortalama trombosit hacmi, Bronşektazi, Çocukluk çağı 


\section{INTRODUCTION}

Bronchiectasis is a progressive condition of irreversible bronchial dilatation as an end result of underlying causes that injure airways. ${ }^{1}$ Bronchiectasis unrelated to cystic fibrosis (CF) presented as recurrent pulmonary infections or persistant airway inflammation, is still an important and common cause of respiratory morbidity in developing countries. ${ }^{2}$ Recurrent exacerbations lead to progressive destruction of lung parenchyma, deterioration of lung functions and results in poor quality of life and eventually respiratory failure. $^{1-3}$

There are no standardized diagnostic tests to predict exacerbations and estimate the progression of the disease for all ages of children. ${ }^{1,4,5}$ It is mostly challenging to obtain sputum in small children or to differentiate pathogens from sputum which may contaminated by upper respiratory tract colonising pathogens., ${ }^{2,6,7}$ Besides, chest radiography and spirometric analysis are not sensitive enough in monitoring disease progression and predicting exacerbations. ${ }^{8,9,10}$

Novel and appropriate parameters are needed to predict exacerbations and follow disease activity in children. It is known that platelets play a role in either pathogenesis of chronic inflammation during the development of bronchiectasis or progression and exacerbation of the disease. To our knowledge, mean platelet volume (MPV) values have not been assessed in children with non-CF bronchiectasis, yet. In the present study, we aimed to investigate MPV values in children with non-CF bronchiectasis during non-exacerbation and exacerbation period and to compare the results with age and sex-matched healthy control subjects.

\section{MATERIALS AND METHODS}

\section{Study Population}

Data of all children who were diagnosed as nonCF bronchiectasis and followed by pediatric allergy department between July 2010 and July 2012 were reviewed. Eighty-one patients with non-CF bronchiectasis and 79 age and sex-matched healthy individuals were enrolled in the study. The children were considered eligable for participation into the study if the following criterion was met: diagnosis of bronchiectasis confirmed by high-resolution computed tomography (HRCT); accepted as a gold standart for diagnosis of bronchiectasis in patients having recurrent pneumonia, prolonged cough, and sputum production. ${ }^{1}$ Exacerbation criterion was defined as having more than two of the following signs and symptoms of increase in frequency of cough, sputum production with changes in sputum quality, dyspnea, tachpnea, reduced exercise capacity, loss of appetite, weight loss in a short time period, as well as hemoptysis, fever above $38^{\circ} \mathrm{C}$ and clinically determined crackles and wheezing. ${ }^{1,5,6}$ The children with the diagnosis of cystic fibrosis were excluded from the study. Demographic data, age at onset of diagnosis, time interval between first detected symptoms and diagnosis, signs and symptoms at the time of diagnosis and exacerbation, bacterial colonization status, exacerbation frequencies, treatments and laboratuary findings were recorded in regular examination appointments in our out-patient clinic. Following laboratory data at the time of exacerbation and non-exacerbation period were collected from the computerized patient database: complete blood count including white blood cell count (WBC), hemoglobin, platelet count, MPV, mean corpuscular volume (MCV) and C-reactive protein (CRP) levels. These parameters were recorded for healthy children from the same computerized database. A hematological, cardiovascular and metabolic disease which might alter MPV values were defined as exclusion criterias for the present study.

In the aim to avoid any influence on the results, the patients who were under any medications of oral or systemic anti-coagulants, nonsteroid anti-inflammatory drugs and aspirin, which might have adverse effect on the functions of platelets or coagulation abnormalities were excluded. The patients were allowed to use oral antibiotics during exacerbation periods at the time of blood sampling.

The complete blood count analyses are performed in the Coulter analyzer model LH in the central laboratory of our institution. Standart tubes with constant amount of ethylenediaminetetraacetic acid (EDTA) were used. The reference values for MPV is ranged from 7.0-11 fL.

\section{Statistical Analysis}

Data were evaluated by using the Statistical Package for Social Sciences version 13.0 (SPSS for Windows 13.0, Inc., Chicago, IL, USA). Descriptive statistics were expressed as means \pm standard deviation (SD). Comparison of parametric data between groups was performed by Student's two-tailed t-test. Pearson and 


\begin{tabular}{|ll|}
\hline $\begin{array}{l}\text { Table 1. Clinical characteristics of children with non-CF bron- } \\
\text { chiectasis }\end{array}$ \\
\hline Clinical Characteristics & Number of Patients (\%) \\
\hline & (no:81) \\
Gender (M/F) & 44 / 37 \\
Age & $11.8 \pm 4.6$ \\
Age at onset of disease & $8.0 \pm 4.5$ \\
Follow-up period & $4.3 \pm 2.5$ \\
Intermarriage & $36(44.4 \%)$ \\
Failure to thrive & $24(29.6 \%)$ \\
Culture positivity in exacerbation & $31(38.2 \%)$ \\
Lobectomy & $3(3.7 \%)$ \\
\hline
\end{tabular}

between age and gender of patients in bronhiectasis and control groups ( $p>0.05)$. Clinical characteristics of patients are given in Table 1. Causes and comorbidities of bronchiectasis are given in Table 2 .

White blood cell counts were significantly higher in acute exacerbation than non-exacerbation period and each of these values were higher than that of the control group $(\mathrm{p}=0.02, \mathrm{p}=0.001, \mathrm{p}=0.03$; respectively). Platelet counts were higher, whereas $\mathrm{MCV}$ values were lower in the patients with bronchiectasis in both exacerbation and non-exacerbation period than those of the control group. Hemoglobin, MCV levels and platelet counts were not different between children with bronchiectasis among exacerbation and

\begin{tabular}{|c|c|c|c|c|c|}
\hline \multirow[b]{2}{*}{ Characteristics } & \multirow[b]{2}{*}{ Controls } & \multirow[b]{2}{*}{$\begin{array}{l}\text { Children with } \\
\text { bronchiectasis } \\
\text { in non- } \\
\text { exacerbation } \\
\text { period }\end{array}$} & \multirow[b]{2}{*}{$\begin{array}{l}\text { Children with } \\
\text { bronchiectasis } \\
\text { in exacerbation } \\
\text { period }\end{array}$} & \multicolumn{2}{|l|}{$p$-value } \\
\hline & & & & $\begin{array}{l}\text { Controls vs. Children } \\
\text { with non-CF bronchiectasis } \\
\text { in non-exacerbation period }\end{array}$ & $\begin{array}{l}\text { Controls vs. Children } \\
\text { with non-CF bronchiectasis } \\
\text { in exacerbation period }\end{array}$ \\
\hline Number of patients & 79 & 81 & 81 & & \\
\hline WBC (count/ $\mu \mathrm{L})$ & $7.8 \pm 2.2$ & $9.3 \pm 2.4$ & $12.1 \pm 5.6$ & 0.03 & $0.001^{*}$ \\
\hline $\mathrm{Hb}$ & $13.0 \pm 1.0$ & $13.0 \pm 1.8$ & $12.7 \pm 1.9$ & 0.87 & 0.35 \\
\hline MCV & $81.3 \pm 4.4$ & $78.5 \pm 6.3$ & $78.3 \pm 6.4$ & 0.20 & 0.16 \\
\hline $\begin{array}{l}\text { Platelet } \\
\text { (count } \times 10^{3} / \mu \mathrm{L} \text { ) }\end{array}$ & $295 \pm 69$ & $364 \pm 112$ & $383 \pm 113$ & 0.01 & $0.001^{*}$ \\
\hline MPV (fL) & $8.1 \pm 0.5$ & $7.9 \pm 0.7$ & $7.6 \pm 0.6$ & 0.17 & $0.001^{*}$ \\
\hline
\end{tabular}

Spearman's correlation tests were used to evaluate the association between MPV and demographic parameters. $p$ value $<0.05$ was considered as statistically significant.

\section{RESULTS}

The study was consisted of $44(54.3 \%)$ boys and 37 (45.6\%) girls with bronchiectasis and 51 (64.5\%) boys and $38(48.1 \%)$ girls in the healthy control group. The mean age of the patients was $11.8 \pm 4.6$ years in bronchiectasis group and $10.4 \pm 4.0$ years for healthy subjects. There was no significant difference non-exacerbation periods.Comparison of laboratory paramaters of exacerbation period, non-exacerbation period and control groups are given in Table 3.

There was no significant difference between MPV values of non-exacerbation period and controls $(\mathrm{p}>$ 0.05 ). Mean platelet volumes during acute exacerbation period were significantly lower when compared with those of non-exacerbation period and controls $(\mathrm{p}=0.02$ and $\mathrm{p}=001$; respectively). MPV and platelet counts $(\mathrm{r}=-0,502, \mathrm{p}=0,01)$, as well as WBC and hemoglobin levels were inversely correlated with each other in exacerbation period $(r=-439, \mathrm{p}=0.00)$. 


\begin{tabular}{|c|c|c|c|}
\hline Characteristics & $\begin{array}{l}\text { Children with bronchiectasis } \\
\text { in non-exacerbation period }\end{array}$ & $\begin{array}{l}\text { Children with bronchiectasis } \\
\text { in exacerbation period }\end{array}$ & $p$-value \\
\hline WBC (count/ $\mu \mathrm{L})$ & $9.3 \pm 2.4$ & $12.1 \pm 5.6$ & $0.02^{*}$ \\
\hline $\mathrm{Hb}(\mathrm{g} / \mathrm{dL})$ & $13.0 \pm 1.8$ & $12.7 \pm 1.9$ & 0.41 \\
\hline MCV (fL) & $78.5 \pm 6.3$ & $78.3 \pm 6.4$ & 0.78 \\
\hline 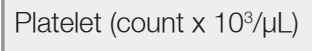 & $364 \pm 112$ & $383 \pm 113$ & 0.28 \\
\hline MPV (fL) & $7.9 \pm 0.7$ & $7.6 \pm 0.6$ & $0.02^{*}$ \\
\hline
\end{tabular}

Patients' age, sex, atopy status, culture positivity and the pathogens causing exacerbation, severity of disease and the drugs used for the treatment have no significant effect on MPV values in exacerbation pe$\operatorname{riod}(\mathrm{p}>0.05)$.

\section{DISCUSSION}

The exact etiology and triggering factors are still unknown for the development of non-CF bronchiectasis and its exacerbations. It is hypothesized that the mechanisms of the disease seems to be the end result of being susceptible to some infectious agents and a widespread pulmonary damage after intense immune response. There are no stardardized diagnostic tests to predict the timing of exacerbations of bronchiectasis in children with any objective parameters. ${ }^{1,5,7} \mathrm{In}$ infants and pre-school children with bronchiectasis, it is mostly challenging to obtain high quality sputum. Moreover, chest radiography ${ }^{9}$ and spirometric tests are not sensitive enough to predict the exacerbations. ${ }^{8,10}$

In the present study, MPV values are found significantly lower during acute exacerbation periods of bronchiectasis when compared to non-exacerbation periods and the values of healthy children. Additionally, we demonstrate an inverse correlation between platelet counts and MPV values in exacerbation periods of bronchiectasis. The patients in infectious period tend to have smaller size of platelets when compared to the values of the patients in recovery period. In recent studies, it is shown that the mediators secreted from platelets for leucocyte recruitment, play a role in inflammation cascade which takes place in exacerbation periods and during progressive pulmonary damage, particularly in CF patients..$^{11,12}$ In our previous study, we showed a decrease in MPV levels in children with $\mathrm{CF}$ in both exacerbation and non-exacerbation periods. We speculated that suggested that some cytokines including IL-6 were detected higher in $\mathrm{CF}$ due to the chronic inflammation, particularly in exacerbation periods and elevated platelet counts with lower MPV levels in CF disease might be related to increased IL-6 levels. ${ }^{13}$ As in CF, platelets might play an important role either in chronic inflammation of non-CF bronchiectasis or in progression of the disease. $^{1,12,14}$

It is well known that, platelet volume is directly correlated with platelet function and activation. ${ }^{15}$ Smaller platelets have lower functional capabilities than the larger ones. Also, platelet recruitment and trombocytosis is directly related with the platelet volume. Thus, MPV might be used as an indicator of platelet function. ${ }^{15,16}$

Some recent studies reported that increased MPV values have been directly related with metabolic syndromes including diabetes, obesity, and myocardial infarction particularly in adult population..$^{17,18}$ In diabetes and obesity, altered platelet morphology and function is essential and larger and more active platelets are more likely to be associated with an increased risk for vascular disease and myocardial infarction. ${ }^{18,19}$

The results of the studies including infectious diseases are debated. Becchi et al. ${ }^{20}$ demonstrated a decrease in MPV values which was directly affecting mortality rate in survivors of acute sepsis. The MPV values 
and platelet counts were negatively and non-linearly correlated with the mortality in septic patients. ${ }^{20} \mathrm{On}$ the contrary, Bessman had observed a parallel trend between MPV values and platelet counts during the course of sepsis in adults. ${ }^{21}$ In addition, an increase in levels of MPV in acute upper urinary tract infectious were reported. ${ }^{22}$ Increased MPV levels might be detected as a result of either the development of more invasive disease or the unreponsiveness to the antibiotic treatment. ${ }^{23}$ The variety in results might be related to methodological differences in study designs. Moreover, MPV values are not static values, ranges widely according to blood sampling, storage, drugs and timing between sampling and analysis. ${ }^{24}$

This present study is in agreement with previous studies involving chronic inflammatory diseases in which clinical remission is interrupted by acute episodes such as ulcerative colitis, ${ }^{25}$ Crohn's disease, ${ }^{26}$ ankylosing spondylitis, rheumatoid arthritis, ${ }^{27}$ and familial Mediterranean fever. ${ }^{28,29}$ These studies reported that MPV levels were significantly lower in chronic course of the disease and the decrease is intimately correlated with the disease activity. Thus, MPV values might be used as an indicator for both chronic inflammation and acute exacerbation periods. ${ }^{25-29}$

Pro-inflammatory cytokines and mediators including IL-6, interleukin-8 (IL-8), TNF- $\alpha$ and intercellular adhesion molecule-1 (ICAM-1) have a role in inflammatory cascade both in disease progression and in exacerbations of bronchiectasis. ${ }^{30}$ Interleukin-6 is often used as a marker of systemic activation of pro-inflammatory cytokines. ${ }^{31}$ Recently, a significant increase in IL-6 among other cytokines in bronchoalveolar lavage fluid and sputum in patients with bronchiectasis was demonstrated. ${ }^{32,33}$ This inflammatory reaction was exaggerated in subjects colonized by microorganisms with a clear relationship to the bronchial bacterial load.

We speculate that several mechanisms might be responsible for decreased MPV values in children with non-CF bronchiectasis during both exacerbation periods and non-exacerbation periods. Our hypothesis might be explained by overproduction of inflammatory cytokines including IL-6 which stimulate megakaryopoiesis with subsequent production and release of small sized platelets from the bone marrow. Regarding the effects of IL-6 on trombocytosis, it might be hypothesized that lower MPV values in children with bronchiectasis related to IL-6 levels especially in exacerbation periods. Other mechanism might be related with consumption of larger and more active platelets in the early stages of inflammation or during the exacerbations. We speculate that, there might be a direct relationship between inflammation and platelet function in bronchiectasis; although little is known about the definite pathophysiological mechanisms of bronchiectasis to define the role of platelets in acute inflammation.

Limitations: The main limitations of this study is its retrospective design and limited number of patient enrollment. The antibiotic usage during exacerbation periods might effect the volume of functions of platelets.

\section{Conclusion}

The present study, for the first time, showed the discriminative value of MPV in non-CF bronchiectasis during acute exacerbation in children. MPV is a costeffective, easy performed test which might be a useful marker for the assessment of disease activity and might give more objective information when compared to other diagnostic tests. Further prospective studies with high number of participants are needed to investigate the role of MPV, platelets and their relationships with pro-inflammatory cytokines either in bronchiectasis or other respiratory diseases.

\section{REFERENCES}

1. Chang AB, Reddind GJ. Bronchiectasis. In: Chernick V, Boat T, Wilmott RW, Bush A, Kendig EL, editors. Kendig's disorders of respiratory tract in children. Philadelphia, WB Saunders Company, 2006: 463-476.

2. Karadag B, Karakoc F, Ersu R, et al. Non-cystic fibrosis bronchiectasis in children: a persisting problem in developing countries. Respiration 72 (Suppl 3): 233-238, 2005.

3. Wilson CB, Jones PW, O'Leary CJ, Cole PJ, Wilson R. Validation of the St. George's respiratory questionnaire in bronchiectasis. Am J Respir Crit Care Med 156 (Suppl 2): 536541, 1997.

4. Chang $A B$, Bilton D. Exacerbations in cystic fibrosis: 4-noncystic fibrosis bronchiectasis. Thorax 63 (Suppl 3): 269-276, 2008.

5. Chang AB, Redding GJ, Everard ML. Chronic wet cough: protracted bronchitis, chronic suppurative lung disease and bronchiectasis. Pediatr Pulmonol 43 (Suppl 6): 519-31, 2008.

8. Li AM, Sonnappa S, Lex C, et al. Non-CF bronchiectasis: does knowing the aetiology lead to changes in management? Eur Respir J 26 (Supp 1): 8-14, 2005. 
7. Angrill J, Agusti C, de Celis R, et al. Bacterial colonization in patients with bronchiectasis. Microbiological pattern and risk factors. Thorax 57: 15-19, 2002.

9. Currie DC, Cooke JC, Morgan AD, et al. Interpretation of bronchograms and chest radiographs in patients with chronic sputum production. Thorax 42 (Suppl 4): 278-284, 1987.

10. Marchant JM, Masel JP, Dickinson FL, Masters IB, Chang AB. Application of chest high-resolution computer tomography in young children with cystic fibrosis. Pediatr Pulmonol 31: 24-29, 2001.

11. O'Sullivan BP, Michelson AD. The inflammatory role of platelets in cystic fibrosis. Am J Respir Crit Care Med 173: 483490, 2006.

12. Weyrich AS, Lindemann S, Zimmerman GA. The evolving role of platelets in inflammation. J Thromb Haemost 1: 1897-905, 2003.

13. Uysal P, Tuncel T, Olmez D, et al. The role of mean platelet volume predicting acute exacerbations of cystic fibrosis in children. Annals of Thorac Med 6: 227-230, 2011.

14. O'Sullivan BP, Michelson AD. The inflammatory role of platelets in cystic fibrosis. Am J Respir Crit Care Med 173: 483490, 2006.

15. Martin JF, Trowbridge EA, Salmon G. The biological significance of platelet volume: Its relationship to bleeding time, thromboxane B2 production and megakaryocyte nuclear DNA concentration. Thromb Res 32: 443-460, 1983.

16. Thompson CB, Eaton KA, Princiotta SM. Size dependent platelet subpopulations: relationship of platelet volume to ultrastructure, enzymatic activity, and function. $\mathrm{Br} \mathrm{J}$ Haematol 50: 509-519, 1982.

17. Tavil Y, Sen N, Yazici HU, et al. Mean platelet volume in patients with metabolic syndrome and its relationship with coronary artery disease. Thromb Res 120 (Suppl 2): 245-250, 2007.

18. Khandekar MM, Khurana AS, Deshmukh SD, Kakrani AL, Katdare AD, Inamdar AK. Platelet volume indices in patients with coronary artery disease and acute myocardial infarction: an Indian scenario. J Clin Pathol 59 (Suppl 2): 146-149, 2006.

19. Bath PM, Butterworth RJ. Platelet size: Measurement, physiology and vascular disease. Blood Coagul Fibrinolysis 7: 157161, 1996.

20. Becchi C, Al Manyan M, Fabbri LP, et al. Mean platelet volume trend in sepsis: is it a useful parameter? Minerva Anestesiol 72: 749-756, 2006.

21. Bessman JD, Gardner FH. Platelet size in thrombocytopenia due to sepsis. Surg Gynecol Obstet 156: 177-180, 1983.

22. Catal F, Baybek N, Bayrak O, et al. Platelet parameters in children with upper urinary tract infection: Is there a specific response? Renal Failure 30: 377-381, 2008.

23. Van der Lelie J, Von dem Borne AEG. Increased mean platelet volume in septicaemia. J Clin Pathol 36: 693-696, 1983.
24. Gasparyan AY, Satavropoulos-Kalinoglu A, Mikhailidis DP, Douglas KM, Kitas GD. Platelet function in rheumatoid arthritis: Arthritic and cardiovascular implications. Rheumatol Int 31: 153-164, 2011

25. Yuksel O, Helvaci K, Basar O, Koklu S. An overlooked indicator of disease activity in ulcerative colitis: Mean platelet volume. Platelets 20 (Suppl 4): 277-281, 2009.

26. Douda T, Bures J, Rejchrt S, et al. Mean platelet volume (MPV) in Crohn's disease patients. Cas Lek Cesk 145 (Suppl 11): $870-873,2006$

27. Kisacik B, Tufan A, Kalyoncu U, et al. Mean platelet volume (MPV) as an inflammatory marker in ankylosing spondylitis and rheumatoid arthritis. Joint Bone Spine 75: 291-294, 2008.

28. Baykal Y, Saglam K, Yilmaz MI. Serum sIL-2R, IL-6, IL-10 and TNF-alpha level in familial Mediterranean fever patients. Clin Rheumatol 22: 99-101, 2003.

29. Gang N, Drenth JP, Langevitz P. Activation of the cytokine network in familial Mediterranean fever. Rheumatol 26: 890897.

30. Khair OA, Davies RJ, Devalia JL. Bacterial-induced release of inflammatory mediators by bronchial epithelial cells. Eur Respir J 9: 1913-1922, 1996.

31. Barton BE. IL-6: insights into novel biological activities. Clin Immunol Immunopathol 85:16-20, 1997.

32. Angrill J, Agusti $\mathrm{C}$, De Celis R, et al. Bronchial inflammation and colonization in patients with clinically stable bronchiectasis. Am J Respir Crit Care Med 164: 1628-1632, 2001.

33. Osika E, Cavaillon JM, Chadelat K, et al. Distinct sputum cytokine profiles in cystic fibrosis and other chronic inflammatory airway disease. Eur Respir J 14: 339-346, 1999.

\section{Correspondence}

Dr. PInar UYSAL

Adnan Menderes Üniversitesi

Çocuk Sağlığı ve Hastalıkları Anabilim Dalı

Allerji-Immunoloji Bilim Dalı

AYDIN / TURKEY

İnciralti, IZMIR / TURKEY

Tel: (+090.256) $4441256 / 1305$

e-mail: druysal.pinar@gmail.com 